\title{
Comparative techno-economic analysis of ORC and gasification for bioenergy applications
}

\author{
A. Rentizelas ${ }^{\mathrm{a}, *}$, S. Karellas ${ }^{\mathrm{b}}$, E. Kakaras ${ }^{\mathrm{b}}$, I. Tatsiopoulos ${ }^{\mathrm{a}}$ \\ a Sector of Industrial Management and Operational Research, National Technical University of Athens, Heroon Polytechniou 9, 15780 Athens, Greece \\ ${ }^{\mathrm{b}}$ Laboratory of Steam Boilers and Thermal Power Plants, National Technical University of Athens, Heroon Polytechniou 9, 15780 Athens, Greece
}

\section{A R T I C L E I N F O}

\section{Article history:}

Received 17 July 2007

Received in revised form 24 March 2008

Accepted 20 October 2008

Available online 4 December 2008

\section{Keywords:}

Economic evaluation

Biomass

Trigeneration

Organic Rankine cycle

Gasification

\begin{abstract}
A B S T R A C T
The use of biomass for decentralized energy production has undergone a significant development the last years. The fact that this fuel is $\mathrm{CO}_{2}$-free provides many advantages in European and world aims for sustainable energy sources. Biomass trigeneration is a relatively new concept, which has the potential to improve the bioenergy economics for areas with warm climate, for which traditional biomass cogeneration was unfeasible. This concept can be applied with various energy conversion technologies, two of which are investigated in this paper: ORC and gasification. Both technologies are applied for a specific case study. The technological and financial comparison of the two technologies shows that gasification offers improved yield for the investment, mainly due to the higher electrical efficiency factor. However, attention should be placed to the increased investment risk of gasification projects, which could be an aversive factor for some investors.
\end{abstract}

(c) 2008 Elsevier Ltd. All rights reserved.

\section{Introduction}

Biomass is one of the oldest fuels which have been used by mankind for cooking and boiling water. Nowadays biomass seems to be a very promising renewable fuel, and various studies forecast an increase in its contribution to the future energy supply, both at a regional and at a global level [1]. This is mainly due to the fact that it is a $\mathrm{CO}_{2}$-free or $\mathrm{CO}_{2}$-neutral fuel. That statement is linked with the fact that during the combustion of biomass, the amount of $\mathrm{CO}_{2}$ which is released is equal to the amount of $\mathrm{CO}_{2}$ that has been assimilated from the plant during its growth. Contrary to natural rotting of biomass and bio-waste in the forest or in disposal areas, no greenhouse gases like $\mathrm{CH}_{4}$ are released during the combustion [2]. On the other hand, the collection and gathering of biomass is performed by the use of collection machines which are producing additional $\mathrm{CO}_{2}$ that should be taken under consideration in the total $\mathrm{CO}_{2}$ balance, together with the case of using fertilizers for the growing of the plants, since their production is followed by the release of $\mathrm{CO}_{2}$. Apart from the zero $\mathrm{CO}_{2}$ equilibrium, biomass has a comparatively low environmental impact; the content in $\mathrm{N}$ and $\mathrm{S}$ in the fuel composition is very low and so are the emissions of $\mathrm{NO}_{x}$ (fuel $\mathrm{NO}_{x}$ ) and of $\mathrm{SO}_{2}$ [3].

Another fact that should be taken into consideration when using biomass as fuel is its low energy density. Fig. 1 presents sche-

\footnotetext{
* Corresponding author. Tel.: +30 210 7722383; fax: +30 2107723571

E-mail address: arent@central.ntua.gr (A. Rentizelas).
}

matically in a qualitative way, how much biomass (in various forms) is needed in order to have the same power production as with coal. That is why the power production with biomass fuel makes sense only when it is used in decentralized or small to medium scale applications, in which the logistics cost is kept at a reasonable level, due to the short transportation distances required [4]. Furthermore, the seasonality that characterizes the availability of most biomass types (especially agricultural residues) creates many problems in the biomass logistics, such as increased warehousing requirements and seasonal use of resources. For this reason, some attempts have been made to deal with this problem by considering the simultaneous use of multiple biomass sources [5].

Biomass has been used at a wide extend for district heating in Northern Europe, and is often used at combined heat and power (CHP) plants [6]. The simultaneous heat and power generation reduces the primary energy consumption, compared to independent generation of the heat and power [7], therefore making it environmentally friendlier and financially more attractive. District heating combined with CHP has been used for many years now, but lately the shift towards biomass-powered CHP is apparent. Biomass CHP with district heating has not been considered a viable option for areas with warm climate up to now, as in these areas traditional cogeneration applications tend to prove financially unviable, due to the short operational time within the year [8]. It is interesting to note that the British Energy Efficiency Office has recommended that a CHP system should run for a minimum of $4500 \mathrm{~h}$ per annum to be financially viable [9]. 


\section{Coal

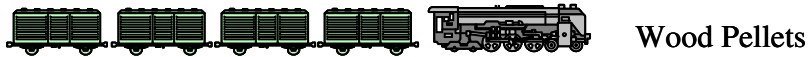

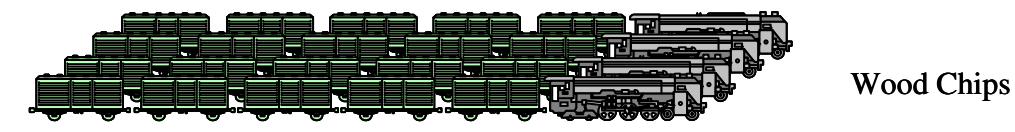

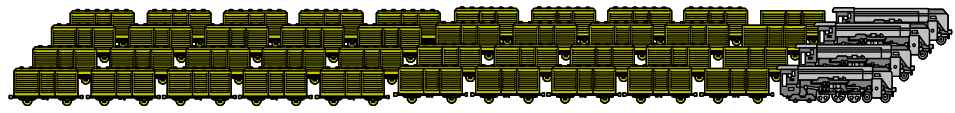

Straw

Bales

Fig. 1. Comparison of biomass with coal.

Lately, the new concept of trigeneration has been introduced. Trigeneration is the simultaneous generation of electricity, heat and cooling, and is considered to be an extension of the cogeneration (CHP), with the addition of absorption chillers that transform heat to cooling. It is also known as combined cooling, heating and power generation (CCHP). Absorption chillers have the ability of easily integrating with cogeneration systems and have lately gained widespread acceptance [10], together with the significant reduction of their price.

The economics of trigeneration appear to be very favourable, compared to conventional independent cooling, heating and power generation, provided that the cooling and heating load profiles form a relatively long operational timeframe for the trigeneration facility and lead to high annual utilization factor. For example, trigeneration using Stirling engine with Natural Gas has been examined in [11], concluding that such a small-scale system may result in a $33 \%$ reduction of primary energy input with very favourable economics for the investment, which was applied at the Shanghai and Beijing regions. These results provide the incentive for investigating the economics of trigeneration using biomass as the primary fuel source for the European context.

Trigeneration can be realized using various biomass cogeneration technologies, provided that simultaneous electricity and heat generation can be achieved. Gasification is a very promising biomass conversion technology, as it is considered that it may prove to be more cost effective compared to other technologies. Some economic studies even show that biomass gasification plants can be as economical as conventional coal fired plants [12], while other researchers mention that gasification is the only technology among the most cost-efficient ones that is likely to be commercially viable for combining with a spark-ignition gas engine, which is a typical power generation scheme [13]. The other biomass to energy conversion technology which is examined in this work is the biomass combustion generated organic Rankine cycle (ORC) process. This technology is widely used nowadays, but special attention must be drawn to the selection of the appropriate organic fluid [14] and the adjustment of the optimal operation parameters of the cycle, since these two factors play a significant role for the economic feasibility of the system [15]. The economics of biomass-fired ORC have not been thoroughly investigated in the relevant literature. However, some applications have been examined, as in [8], where a biomass-based ORC system with district heating and power generation has been found to be financially attractive, under the condition that a centralized cogeneration ORC plant is considered, rather than a number of distributed, small cogeneration units.

The two technologies selected in this work include biomass gasification, which is a very promising, high-efficiency and relatively capital intensive technology (which is still at a pilot/demonstration stage - not yet fully commercial), and ORC, which is a technology with lower efficiency, lower investment and operational cost, highly standardized, reliable and utilized technology. Both technologies may be applied for medium-scale biomass trigeneration applications, and no direct comparison has been performed up to now in the relevant literature. Though fundamentally different in principle and characteristics, each one of these technologies has its own merits. Therefore it is of high interest to investigate the impact of adopting these technologies in the efficiency and the economics of a trigeneration district energy system.

\section{Model description}

The model, utilized to compare the financial yield of various technological methods for biomass conversion, is a tool that has the ability to simulate a biomass-to-energy supply chain, taking into consideration not only the upstream biomass supply chain up to the energy conversion facility, as most of the researchers do, but also the downstream supply chain of the energy products generated, such as electricity, heat and cooling [16].

The energy conversion facility in the model may be a CHP (combined heat and power) or a trigeneration plant, and provision is made to incorporate the investment and operational costs of a district heating or/and district cooling network. The energy conversion unit consists of two distinct technological devices: a baseload biomass co-generation unit and a peak-load biomass heat boiler, to cover the peak heat loads, as is the common practice in similar cases. In this work the various technological options examined apply solely to the base-load device, whereas the peak-load biomass boiler characteristics remain the same in all scenarios. In all cases, a centralized power plant is considered, as it has been suggested by [8] that distributed cogeneration appears to be less efficient. The heating and cooling generated is transferred via a district energy network to the final consumers. It is assumed that the heating and cooling periods will not overlap, and therefore only one district energy network will be constructed. This assumption significantly reduces the district energy distribution network cost, as in case of simultaneous heating and cooling supply there should be two distinct distribution networks constructed. The district energy system consists of two main parts: firstly, the long-distance heat transfer pipeline, which connects the CHP plant with the terminal station and transfers only heat. The terminal station is located close to the district heating/cooling consumption and contains heat exchangers and the absorption chillers. The second part is the district energy distribution network, which connects the terminal station with the final consumers, supplying them either with heat or cooling, depending on the period of the year.

The simulation model has been coupled with an optimization module, which optimizes the major design and operational characteristics of the whole system, by determining the optimal values of a set of variables. The optimization variables in this work are the rated capacity of the base-load biomass co-generation unit, the 
rated capacity of the peak-load biomass boiler, the yearly biomass quantity to be procured, the geographical positioning of the plant and the biomass inventory at the end of each period (year).

A holistic optimization approach has been adopted, in the sense that all the stages of the biomass-to-energy supply chain have been incorporated, extending from biomass collection and transportation, to energy delivery to the final customers (Fig. 2). More specifically, the customers of the system are the electricity grid for electricity and the district heating and cooling consumers for heat and cooling. Optimization is performed on the basis of the investment analysis criteria selected. The rationale behind the holistic optimization methodology adopted is that focusing optimization on only one of the biomass-to-energy supply chain's discrete phases does not necessarily lead to an overall optimum solution for the complete system.

An overview of the model structure is presented below:

$$
\begin{aligned}
\max \mathrm{NPV}= & \mathrm{PV}(\text { Revenues })-\mathrm{PV}(\text { Expenses }) \\
& - \text { Investment Costs }
\end{aligned}
$$

where (1) is the objective value of the optimization problem. NPV is the net present value of the investment and PV stands for present values of cashflows.

The symbol $R$ stands for annual revenues, $C$ for annual costs and $I$ for investment costs. The present value of Revenues, Expenses and Investment Costs are presented in Eqs. (2)-(4), respectively.

$$
\begin{aligned}
\mathrm{PV}(\text { Revenues })= & \left(R_{\text {Electricity }}+R_{\text {Electricity Capacity }}+R_{\text {Heating }}+R_{\text {Cooling }}\right. \\
& \left.+R_{\text {Greenhouse Gas Trading }}\right)(1-[1+(i-\rho) \\
& \left./(1+\rho)]^{-N}\right) /(i-\rho)
\end{aligned}
$$

where $i$ is the interest rate, $\rho$ the inflation rate and $N$ the investment lifetime.

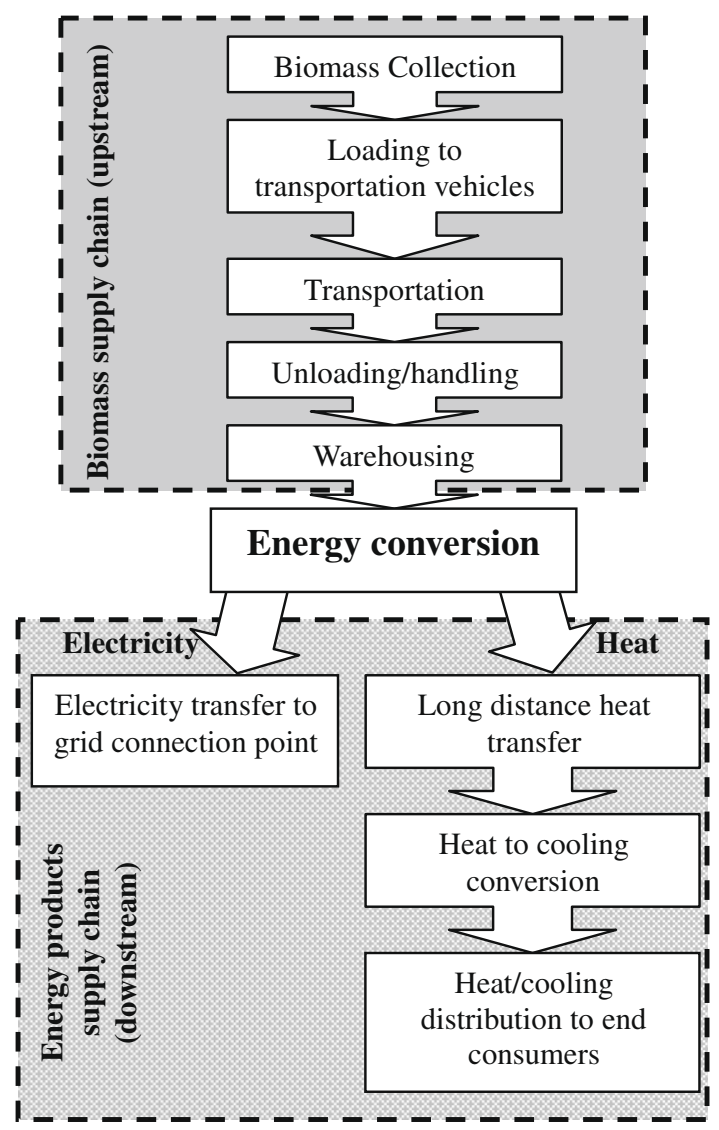

Fig. 2. System modelled.

$$
\begin{aligned}
\mathrm{PV}(\text { Expenses })= & \left(C_{\text {Biomass Purchasing }}+C_{\text {Biomass Transport }}\right. \\
& +C_{\text {Warehousing }}+C_{\mathrm{CHP} O \& \mathrm{M}}+C_{\text {Boiler O\&M }} \\
& +C_{\text {Electricity Transmission }}+C_{\text {District Heating O\&M }} \\
& \left.+C_{\text {Cooling Equipment O\&M }}\right)(1-[1+(i-\rho) \\
& \left./(1+\rho)]^{-N}\right) /(i-\rho)
\end{aligned}
$$

where O\&M stands for Operation and Maintenance.

$$
\begin{aligned}
\text { Investment Costs }= & I_{\text {Warehouse }}+I_{\text {CHP plant }}+I_{\text {Boiler }} \\
& +I_{\text {Electricity Transmission }}+I_{\text {District Heating }} \\
& +I_{\text {Cooling }}
\end{aligned}
$$

Applying the model for the same case study application but for different energy conversion technological processes offers the possibility of comparing the project's financial yield for each process. This comparison may lead to interesting conclusions, especially since real biomass availability raw data is used.

\section{Available biomass conversion technologies}

There are four main categories of conversion technologies for energy exploitation of biomass: direct combustion processes, thermochemical processes, biochemical processes and agrochemical processes [17]. In this article, technologies belonging to the first two categories will be investigated.

\subsection{Biomass combustion}

The most common way to convert biomass into heat and power is its combustion. Spliethoff [18] describes analytically all the combustion methods that can be used in order to burn efficiently several types of biomass. The heat from biomass combustion can be further transferred into a water-steam cycle, or an organic Rankine cycle (ORC), producing power and heat. A first approach of such a system was done in the literature by Obernberger [19]. The main advantage of the use of ORC in biomass combustion processes is that this technology is appropriate for decentralized applications and it is the only proven method for power generation up to $1 \mathrm{MW}_{\mathrm{el}}$. The electrical efficiency of the ORC process lies between $6 \%$ and $17 \%$. This efficiency is linked with the maximum heat recovery and the thermal efficiency of the boiler. Examples of ORC plants can be found in central Europe (Stadtwärme Lienz Austria $1000 \mathrm{~kW}_{\mathrm{el}}$, Sauerlach Bavaria $700 \mathrm{~kW}_{\mathrm{el}}$, Toblach South Tyrol $1100 \mathrm{~kW}_{\mathrm{el}}$, Fußach Austria $\left.1500 \mathrm{~kW}_{\mathrm{el}}[20,21]\right)$.

Fig. 3 presents the combined heat and power production when biomass combustion is combined with the ORC process. More specifically, the heat produced in the combustion chamber is transferred to a thermal oil which is first preheated from the exhaust gas [14]. The thermal oil generates the organic steam which is expanded in the expander. The heat of the condenser of the process is used for the district heating (DH) network in which, the heat produced can be either used for heating purposes, or, with the use of absorption chillers, for cooling applications.

\subsection{Biomass gasification}

Biomass gasification is the latest generation of biomass energy conversion processes $[3,22]$ and is being used to improve the efficiency and to reduce the investment costs of biomass electricity generation, according to [17]. On the other hand the synthesis of second generation fuels from the syngas of biomass gasification gives a motivation to the improvement of the gasification process and the research in this area [23]. 
One of the most successful biomass gasification concepts is installed in the Austrian village Güssing, which is a circulating fluidised bed gasifier, producing about 2.0 MW electric power and 4.5 MW thermal power, from a fuel input of $8 \mathrm{MW}$. The gas is used, after having been cleaned, in a gas engine and in a district heating boiler for CHP production [24]. A typical combination of the gasification process with an internal combustion (IC) engine is presented in Fig. 4.

As it can be seen in Fig. 4 biomass is gasified in the gasifier, either with air, in which case autothermal gasification takes place, or with water steam, in which case allothermal gasification takes place. In the second case, the heat required for the gasification process is transferred to the gasifier either by transporting bed material from a combustion chamber into the gasifier (e.g. Güssing gasifier [25] and Blaue Turm gasifier [26]) or by using liquid metal heatpipes which transfer the heat from a combustion chamber to the gasifier (e.g. Biomass Heatpipe Reformer [27]). In this paper the case of autothermal gasifiers (gasification with air) is dis- cussed. In the above described concept (Fig. 4), electrical power is produced in the generator which is coupled with the IC engine. The gas before entering the gas engine, is treated in the gas treatment system (Cyclone, filter, cooling of the gas) as done in the state of the art gasification plants [28]. District Heat is produced from the exhaust heat of the engine. This heat is coming from the cooling water of the engine and the turbocharger, but also from the heat content of the exhaust gas of the engine. Other possible uses of the produced gas from biomass gasification are its combustion in a gas turbine of a biomass integrated gasification combined cycle, as presented by Rodrigues et al. [29], or the use of the gas in microturbines [30] or fuel cell systems [30,31] for CHP production.

\section{Investment analysis}

The investment analysis criterion used as the objective function of the optimization problem is the net present value (NPV) of the investment, due to its inherent advantages, its common use as a

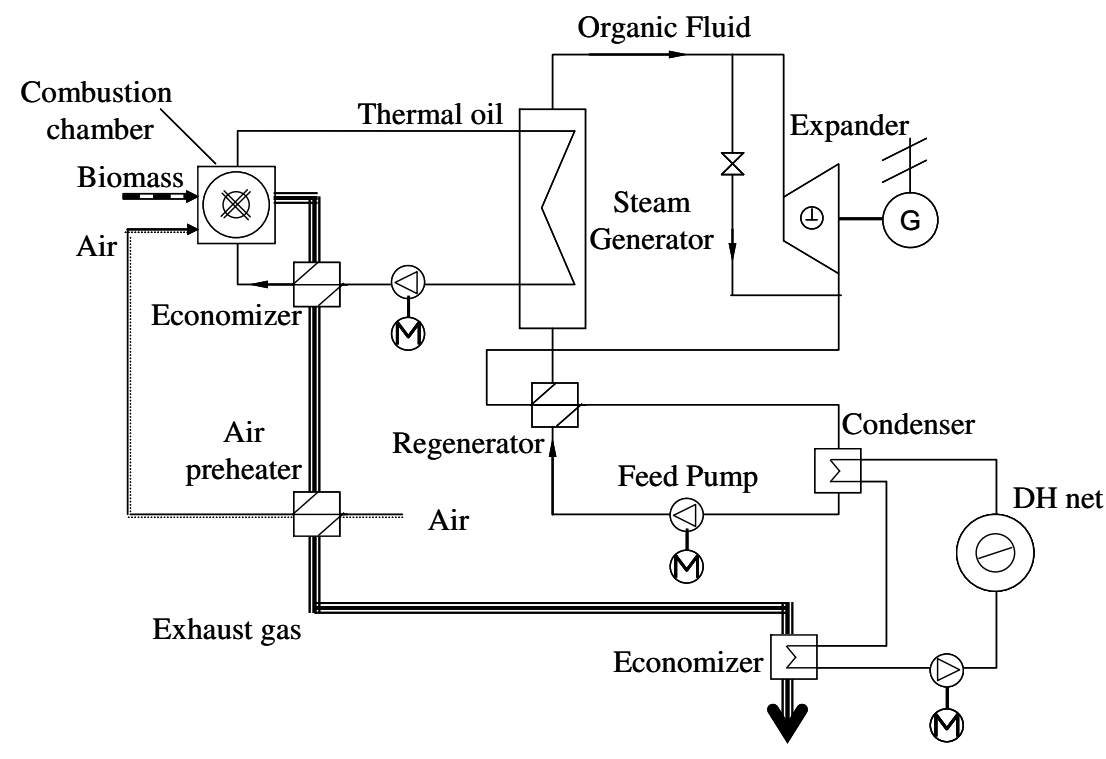

Fig. 3. CHP production with biomass combustion and ORC.

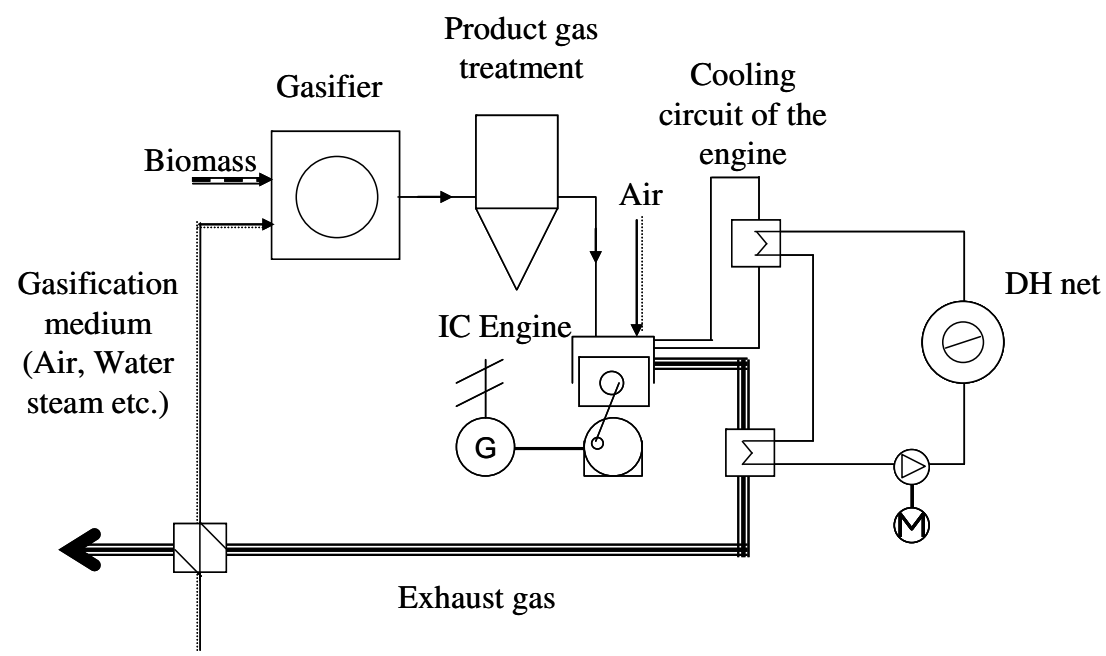

Fig. 4. CHP production with biomass gasification and IC engine. 
project appraisal method in business practice [32] and its widespread use in relevant cases in the literature [33]. Apart from the NPV, other investment analysis criteria, such as the internal rate of return (IRR) and pay back period (PBP) have also been calculated for the optimum system parameters determined by the optimization method. It is always useful not to rely solely on a single investment analysis criterion, as the information that can be drawn from each one of them may support the decision of different types of investors.

\section{Case study}

The model has been implemented for a case study that concerns the investment analysis of a trigeneration power plant, given the demand of a specific customer for heat and cooling. The customer is considered to be a local community using heat mainly for space heating and domestic hot water applications, whereas cooling is primarily used for space cooling. The district energy customer is a local community in Greece of about 300 houses, for which the heat and cooling demand profiles are available. The heating and cooling demand is highly dependent on the climatic conditions (ambient temperature), therefore it is characterized by high variability. The biomass-to-energy conversion facility is considered to operate at heat-match mode, as the main objective of the power plant is to fully satisfy the thermal and cooling needs of the customers. The electricity generated during the operation of the cogeneration (base-load) module of the power plant is always absorbed by the national grid, due to the favourable legislative framework that gives priority to renewably generated electricity.

The main revenue sources of the power plant under consideration are electricity sales to the national grid, heat and cooling supplied to the customers via a district heating network, as well as trading of the Emissions Reduction Units (ERU's). The price of heat is assumed to be a fixed percentage of the cost of heat obtained by using oil whereas the price of cooling is a fixed percentage of the cost of cooling obtained by electrical compression chillers.

A base-load co-generation module and a biomass boiler for peak-load heat production comprise the energy exploitation module. Heat produced from the abovementioned devices will be transferred by the main district heating pipeline to a position near the final consumers (terminal station). The same distribution network is used for district heating and cooling. The plant is assumed to operate in heat-match mode, to serve the heating and cooling needs of the customers. The electricity produced will be sold directly to the grid, at prices determined by the Greek energy authority.

Table 1

Main case study data.

\begin{tabular}{|c|c|c|}
\hline & ORC & Gasification \\
\hline$\eta_{\mathrm{el}}(\%)$ & 14 & 26 \\
\hline$\eta_{\text {th }}(\%)$ & 75 & 55 \\
\hline$\eta_{\text {total }}(\%)$ & 89 & 81 \\
\hline Power-to-heat ratio (\%) & 18.7 & 47.3 \\
\hline Size of reference plant $\left(\mathrm{kW}_{\mathrm{el}}\right)$ & 1000 & 1000 \\
\hline Investment cost of reference plant $\left(€ / \mathrm{kW}_{\mathrm{el}}\right)$ & 2760 & 2500 \\
\hline Subsidy on investment (\%) & 40 & 40 \\
\hline COP absorption chiller & 0.733 & 0.744 \\
\hline Operational \& Maintenance cost (\% of inv. Cost/yr) (\%) & 3.5 & 6 \\
\hline DH forward temperature $\left({ }^{\circ} \mathrm{C}\right)$ & 92 & 120 \\
\hline DH return temperature $\left({ }^{\circ} \mathrm{C}\right)$ & 65 & 65 \\
\hline Electricity purch. price ( $€ / \mathrm{MW} \mathrm{h})$ & 68.42 & 68.42 \\
\hline Oil price $(€ / \mathrm{kg})$ & 0.5 & 0.5 \\
\hline Price of $\mathrm{tCO}_{2}\left(€ / \mathrm{tCO}_{2}\right)$ & 15 & 15 \\
\hline Heat consumers & 300 & 300 \\
\hline Average distribution network length per consumer (m) & 20 & 20 \\
\hline
\end{tabular}

The primary fuel used for both cases is a mix of three locally available woody biomass types, namely olive tree prunings, almond tree prunings and peach tree prunings. Using a combination of biomass types instead of a single type may have considerable logistical advantages and cost reduction [16,34]. All three biomass types have similar fuel properties and heating value, can be handled with the same equipment and are considered agricultural residues with no important alternative use, therefore they can be purchased in relatively low price. The price has been assumed to be $30 € / t_{\text {wet }}$ for all biomass types, including loading cost to the transportation vehicles. The main data used for the case study is presented in Table 1.

\section{Results and discussion}

The calculations for the characteristics of each system design to satisfy the end customer heat and cooling needs have been performed based on an optimization model, which focuses on total system yield maximization [16]. The optimum values for the most interesting parameters are presented in Table 2 . It should be noted that in both cases, the nominal thermal power of the power plants and the biomass boiler is practically equivalent, as they are designed to satisfy the same heat and cooling load profile. The slightly increased CHP nominal thermal power in the Gasification case can be attributed to the increased heat losses due to higher temperature of the heat transfer medium $\left(120^{\circ} \mathrm{C}\right.$ forward temperature as opposed to $92{ }^{\circ} \mathrm{C}$ for ORC). The main difference lays in the nominal electrical power, due to the significantly higher power-toheat ratio that gasification can achieve, therefore having 139\% higher electrical power than ORC. The increased electricity generation capacity leads also to increased biomass requirement in the case of gasification, as it can be seen in Table 2. In total, gasification requires $34.3 \%$ more biomass than ORC.

The energy generated each month for the two technological scenarios is presented in Tables 3 and 4 . The thermal energy gener-

Table 2

Main system characteristics.

\begin{tabular}{lrc}
\hline & ORC & Gasification \\
\hline CHP nominal electrical power $(\mathrm{kW})$ & 390 & 931 \\
CHP nominal thermal power $(\mathrm{kW})$ & 2090 & 2113 \\
Boiler nominal thermal power $(\mathrm{kW})$ & 985 & 985 \\
Olive tree prunings $(\mathrm{t} / \mathrm{yr})$ & 1200 & 1652 \\
Almond tree prunings $(\mathrm{t} / \mathrm{yr})$ & 2113 & 2011 \\
Peach tree prunings $(\mathrm{t} / \mathrm{yr})$ & 2334 & 3922 \\
\hline
\end{tabular}

Table 3

Energy generated by ORC.

\begin{tabular}{|c|c|c|c|}
\hline \multirow[t]{2}{*}{ Month } & \multicolumn{3}{|l|}{ ORC } \\
\hline & $\begin{array}{l}\text { Electricity } \\
\text { (MW h) }\end{array}$ & $\begin{array}{l}\text { Thermal CHP } \\
(\mathrm{MW} \mathrm{h})\end{array}$ & $\begin{array}{l}\text { Thermal boiler } \\
(\mathrm{MW} \text { h) }\end{array}$ \\
\hline January & 281.0 & 1505.1 & 47.3 \\
\hline February & 255.0 & 1366.1 & 0.0 \\
\hline March & 217.6 & 1165.8 & 0.0 \\
\hline April & 134.0 & 717.8 & 0.0 \\
\hline May & 154.6 & 828.0 & 0.0 \\
\hline June & 274.9 & 1472.4 & 0.0 \\
\hline July & 281.0 & 1505.1 & 511.9 \\
\hline August & 281.0 & 1505.1 & 506.9 \\
\hline September & 263.0 & 1408.9 & 0.0 \\
\hline October & 136.8 & 733.1 & 0.0 \\
\hline November & 178.8 & 958.1 & 0.0 \\
\hline December & 281.0 & 1505.1 & 0.0 \\
\hline $\begin{array}{l}\text { Total } \\
\text { (yearly) }\end{array}$ & 2738.5 & 14670.7 & 1066.2 \\
\hline
\end{tabular}


Table 4

Energy generated by gasification.

\begin{tabular}{lccc}
\hline Month & Gasification & & \\
\cline { 2 - 4 } & $\begin{array}{l}\text { Electricity } \\
(\mathrm{MW} \mathrm{h})\end{array}$ & $\begin{array}{l}\text { Thermal CHP } \\
(\mathrm{MW} \mathrm{h})\end{array}$ & $\begin{array}{l}\text { Thermal boiler } \\
(\mathrm{MW} \mathrm{h})\end{array}$ \\
\hline January & 719.2 & 1521.3 & 47.4 \\
February & 652.6 & 1380.4 & 0.0 \\
March & 556.9 & 1178.0 & 0.0 \\
April & 342.9 & 725.3 & 0.0 \\
May & 389.7 & 824.3 & 0.0 \\
June & 692.9 & 1465.8 & 0.0 \\
July & 719.2 & 1521.3 & 486.7 \\
August & 719.2 & 1521.3 & 481.7 \\
September & 663.0 & 1402.6 & 0.0 \\
October & 347.0 & 734.1 & 0.0 \\
November & 457.6 & 968.1 & 0.0 \\
December & 718.9 & 1520.8 & 0.0 \\
Total & 6979.0 & 14763.3 & 1015.8 \\
$\quad$ (yearly) & & & \\
\hline
\end{tabular}

ated by the power plant, as a sum of the CHP and the boiler modules, is almost equal in both scenarios. It should be noted that the biomass boiler is utilized for three months per year to deliver peakload thermal power, the main peak taking place during the summer. Therefore, one can conclude that cooling load determines the overall peak for the specific application.

As far as electricity generation is concerned, gasification results in yearly generation of $6979 \mathrm{MW}$ h as compared to $2738.5 \mathrm{MW}$ h of ORC. This result is in accordance with the assumptions made for fixed power-to-heat ratio in partial loads and heat-match operation of the power plants. As a result, the significantly lower power-to-heat ratio of ORC results in limited electricity generation, which amounts to only $39.2 \%$ of the respective figure for gasification.

One of the main purposes of this work is to examine the investment yield of these two scenarios. The main results of the investment analysis performed for the optimum parameter values of each scenario are presented in Table 5 .

The investment analysis results clearly show that the gasification option returns double the net present value compared to the ORC in the power plant's economical lifetime (assumed equal to 20 years). However, one should keep in mind that gasification requires a significantly increased investment, and therefore more capital should be raised to perform the project. This difference in the initial capital requirement is accountable for the improved performance of ORC in terms of the internal rate of return and the pay back period values, which are investment analysis criteria that mainly influence investors with short-term perspective. Even for these criteria gasification offers superior performance, although the difference is not as striking as with the NPV criterion. It now remains to indulge into the economics of the two scenarios to identify the reasons for the financial yield superiority of gasification.

The revenue breakdown for the two scenarios is shown in Fig. 5, where all the amounts are present values for the financial lifetime of the investment. It is obvious that revenue related to heat and cooling sales is exactly the same in both scenarios, as the energy demand is fixed. The considerably higher total revenue of gasifica-

Table 5

Investment analysis results.

\begin{tabular}{lll}
\hline & ORC & Gasification \\
\hline NPV $\left(€ * 10^{6}\right)$ & 1.61 & 3.25 \\
IRR (\%) & 14.8 & 18.1 \\
PBP (years) & 9.9 & 7.8 \\
Investment $\left(€ * 10^{6}\right)$ & 2.67 & 3.44 \\
\hline
\end{tabular}

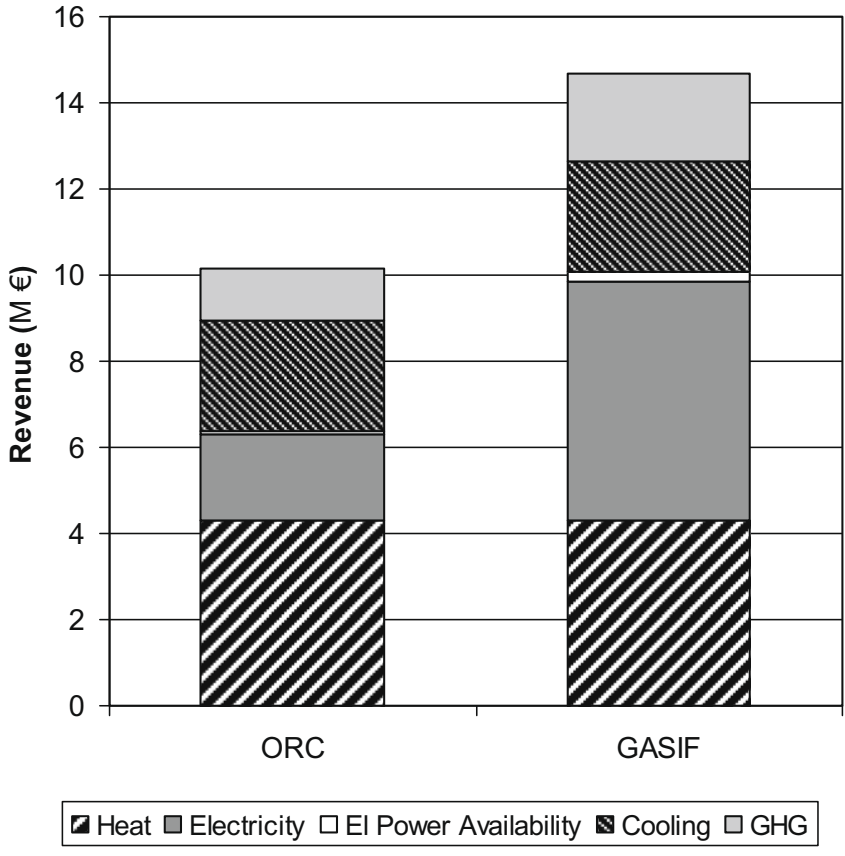

Fig. 5. Revenue breakdown (present values).

tion by $45 \%$ can be primarily attributed to the electricity generation. Income from electricity in the gasification case amounts to 6.76 M€, as compared to $2.07 \mathrm{M€}$ of ORC. It can be said that ORC bases its viability on heat income, whereas gasification's main income source is electricity, which is a higher value product than heat. Furthermore, the increased electricity generation of the gasification plant has a side effect: it allows more emission allowances to be generated, thus leading to increased potential income from allowances trading by almost $71 \%$.

Several cost factors remain unchanged for both scenarios, such as investment and Operation and Maintenance (O\&M) for cooling

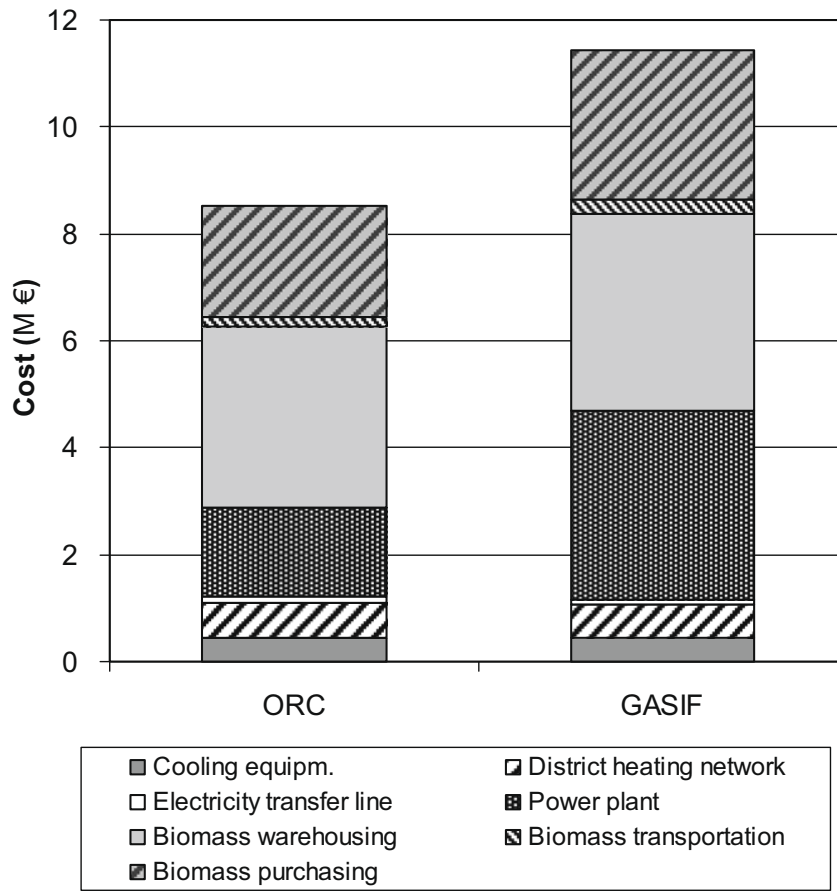

Fig. 6. Cost breakdown (present values). 


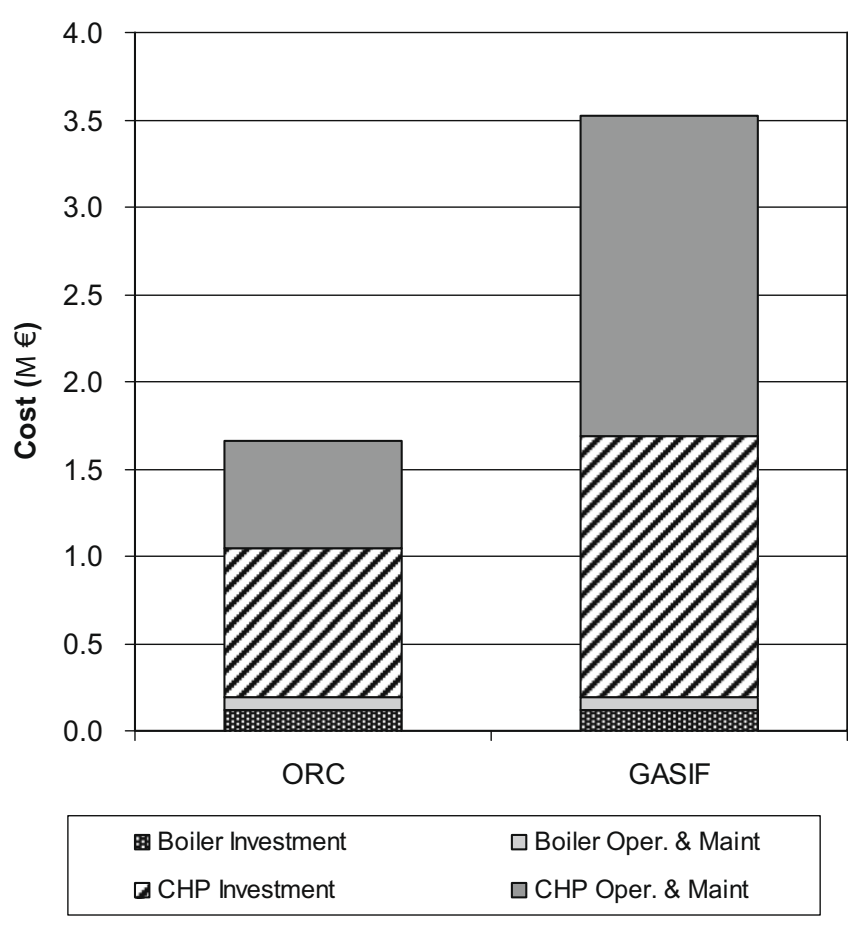

Fig. 7. Power plant-related cost breakdown (present values).

equipment and the electricity transfer line, as can be seen in Fig. 6 . The district heating network investment and Operation and Maintenance are slightly increased by $6.3 \%$ in the ORC case, due to lower temperature of the heat transfer medium that results in requirement for larger pipeline diameter and increased electricity consumption for pumping. Biomass logistics costs are higher by about $19.3 \%$ for the gasification case, as more electricity will be generated and therefore more input energy is necessary. More specifically, biomass purchasing cost is increased by $34.3 \%$, transportation cost by $40 \%$ and warehousing cost by $8.9 \%$. It is apparent that economies of scale take place in the warehousing stage, thus restraining the overall cost increase.

A major increase can be observed for the power plant-related cost in the gasification case by about $112 \%$. One would expect this because of the higher nominal electrical capacity of the gasification plant, as well as the relatively increased Operation \& Maintenance requirements. Fig. 7 constitutes an attempt to analyze further the power plant-related cost for the scenarios examined.

First of all, the investment and Operation and Maintenance cost of the biomass peak-load boiler is the same in both cases. The difference lays in the CHP module, where gasification requires $75 \%$ increased capital for investment and 200\% increased Operation \& Maintenance cost. Therefore it can be concluded that the larger part of the power plant cost difference is due to the higher Operation \& Maintenance cost of the gasification technology. On the other hand, economies of scale restrain the capital cost increase to lower levels.

\section{Conclusions}

In this work, a comparison between the ORC and the gasification technology has been performed both in terms of their technological characteristics, as well as the financial yield of two projects, aiming at serving a specific heating and cooling demand.

ORC technology offers a solution of lower capital requirement and significantly lower Operational \& Maintenance cost in comparison to gasification. Nonetheless, the notably higher power-to-heat ratio of the gasification technology allows increased revenue from electricity generation and offsets by far the higher technology-related cost. Therefore, gasification appears to be a better solution for the potential investors who aim at serving specific heat and cooling needs, offering significantly improved financial yield.

On the other hand, one should keep in mind factors that were not included in this study, as they are difficult to quantify. For example, ORC is a well proven and used technology as opposed to gasification, that is mostly used in pilot/demonstration plants up to now. Furthermore, ORC usually comes in pre-assembled modules, thus significantly reducing installation time and cost. Additionally, the standardization of ORC modules reduces the risk associated with performance and reliability.

Gasification is a promising technology, but is subject to increased risk, due to the lack of standardization. And risk is a factor that may be critical for the decision of an investor, depending on his risk attitude [35].

\section{References}

[1] Yamamoto H, Junichi F, Kenji Y. Evaluation of bioenergy potential with a multiregional global-land-use-and-energy model. Biomass Bioenergy 2001;21:185-203.

[2] Karl J. Decentralised energy systems, new technologies in liberalised energy market (Dezentrale Energiesysteme, Neue Technologien im liberalisierten Energiemarkt). München: Oldenbourg Verlag; 2004 [in German].

[3] Mathieu P, Dubuisson R. Performance analysis of a biomass gasifier. Energy Convers Manage 2002;43:1291-9.

[4] Dornburg V, Faaij A. Efficiency and economy of wood-fired biomass energy systems in relation to scale regarding heat and power generation using combustion and gasification technologies. Biomass Bioenergy 2001;21:91-108.

[5] Papadopoulos D, Katsigiannis P. Biomass energy surveying and technoeconomic assessment of suitable CHP system installations. Biomass Bioenergy 2002;22:105-24.

[6] Bernotat K, Sandberg T. Biomass fired small-scale CHP in Sweden and the Baltic States: a case study on the potential of clustered dwellings. Biomass Bioenergy 2004;27:521-30.

[7] Hendriks C, Blok K. Regulation for combined heat and power in the European Union. Energy Convers Manage 1996;37:729-34.

[8] Chinese D, Meneghetti A, Nardin G. Diffused introduction of Organic Rankine Cycle for biomass-based power generation in an industrial district: a systems analysis. Int J Energy Res 2004;28:1003-21.

[9] Gutteridge S. Expanding market for CHP. Energy World 1995;226:7-10.

[10] Srikhirin P, Aphomratana S, Chungpaibulpatana S. A review of absorption refrigeration technologies. Renew Sustain Energy Rev 2003;7:131-7.

[11] Kong XQ Wang RZ, Huang XH. Energy efficiency and economic feasibility of CCHP driven by Stirling engine. Energy Convers Manage 2004;45:1433-42.

[12] Badin J, Kirschner J. Biomass greens US power production. Renew Energy World 1998;1:40-5.

[13] McKendry P. Energy production from biomass (Part 2): Conversion technologies. Bioresour Technol 2002;83:47-54.

[14] Drescher U, Brüggemann D. Fluid selection for the Organic Rankine Cycle (ORC) in biomass power and heat plants. Appl Therm Eng 2007;27:223-8.

[15] Lee KM, Kuo SF, Chien ML, Shih YS. Parameters analysis on Organic Rankine Cycle energy recovery system. Energy Convers Manage 1988;28(2):129-36.

[16] Rentizelas A. Supply chain optimization models: application in the case of energy exploitation of multiple biomass sources (in Greek). PhD thesis, National Technical University of Athens, Greece; 2007.

[17] Demirbas A. Biomass resource facilities and biomass conversion processing for fuels and chemicals. Energy Convers Manage 2001;42:1357-78.

[18] Spliethoff H. Combustion of solid fuels for power and heat production, methods and state of the art - operation, emissions and rests (Verbrennung fester Brennstoffe zur Strom- und Wärmeerzeugung, Verfahren und Stand der Technik - Wirkungsgrad, Betrieb, Emissionen und Reststoffe). Düsseldorf: VDI Verlag GmbH; 2000 [in German].

[19] Obernberger I. Decentralized biomass combustion: state of the art and future development. Biomass Bioenergy 1998;14(1):33-56.

[20] Duvia A, Gaia M. ORC plants for power production from 0.4 MWe to $1.5 \mathrm{MWe}$ : technology, efficiency, practical experiences and economy. In: 7th Holzenergie symposium, Zürich, Switzerland, 18 October 2002.

[21] Obernberger I, Thonhofer P, Reisenhofer E. Description and evaluation of the new 1000 kWel Organic Rankine Cycle process integrated in the biomass CHP plant in Lienz, Austria. Euroheat Power 2002;10(1):1.

[22] Sharma A. Equilibrium modeling of global reduction reactions for a downdraft (biomass) gasifier. Energy Convers Manage 2008;49:832-42.

[23] Lv P, Yuan Z, Wu C, Ma L, Chen Y, Tsubaki N. Bio-syngas production from biomass catalytic gasification. Energy Convers Manage 2007;48:1132-9.

[24] Hofbauer H, Rauch R, Bosch K, Koch R, Aichernig C. Biomass CHP Plant Güssing a success story. Expert meeting on pyrolysis and gasification of biomass and waste, October 2002, Strasbourg, France. 
[25] Kaushal P, Pröll T, Hofbauer H. Model development and validation: cocombustion of residual char, gases and volatile fuels in the fast fluidized combustion chamber of a dual fluidized bed biomass gasifier. Fuel 2007;86:2687-95.

[26] Mühlen HJ, Schmid C. The Blue Tower - Hydrogen from Biomass, Ecologica material recycling (Der Blaue Turm-Wasserstoff aus Biomasse, Ökologische Stoffverwertung). Report of the Fördergemeinschaft, Wasserstoffreiches Vergasungsgas, December 2003

[27] Metz T, Kuhn S, Karellas S, Stocker R, Karl J, Hein D. Experimental results from the Biomass Heatpipe Reformer. In: Van Swaaij WPM, editor. Second World conference and technology exhibition on biomass, for energy, industry and climate protection, Rome 2004.

[28] Kramreiter R, Url M, Kotik J, Hofbauer H. Experimental investigation of a 125 $\mathrm{kW}$ twin-fire fixed bed gasification pilot plan and comparison to the results of a 2 MW combined heat and power plant (CHP). Fuel Process Technol 2008;89:90-102.

[29] Rodrigues M, Walter A, Faaij A. Performance evaluation of atmospheric biomass integrated gasifier combined cycle systems under different strategies for the use of low calorific gases. Energy Convers Manage 2007;48: 1289-301.

[30] Karellas S, Karl J, Kakaras E. An innovative biomass gasification process and its coupling with micoturbine and fuel cell systems. Energy 2007;33: 284-91.

[31] Fryda L, Panopoulos KD, Kakaras E. Integrated CHP with autothermal biomass gasification and SOFC-MGT. Energy Convers Manage 2008;49:281-90.

[32] Ryan P, Ryan G. Capital budgeting practices of the fortune 1000: how have things changed? J Business Manage 2002;8(4):355-64.

[33] Biezma M, San Cristóbal J. Investment criteria for the selection of cogeneration plants - a state of the art review. Appl Therm Eng 2006;26:583-8.

[34] Nilsson D, Hansson P-A. Influence of various machinery combinations, fuel proportions and storage capacities on costs for co-handling of straw and reed canary grass to district heating plants. Biomass Bioenergy 2001;20: 247-60.

[35] Rentizelas A, Tziralis G, Kirytopoulos K. Incorporating uncertainty in optimal investment decisions. World Rev Entrep, Manage Sustain Dev 2007;3(34):273-83 